\title{
ANALYSES OF CALCIUM INFLUENCE ON THE AISi9CuMnNi ALLOY
}

\author{
Nataša Náprstková', Pavel Kraus', Jaromír Cais', Dana Stančeková², Izabela Miturska
}

1 Jan Evangelista Purkyně University in Ústí nad Labem, Faculty of Production Technology and Management, Pasteurova 1, 400 96, Ústí nad Labem, Czech Republic, e-mail: naprstkova@fvtm.ujep.cz, kraus@fvtm.ujep.cz, cais@fvtm.ujep.cz

2 University of Žilina, Faculty of Mechanical Engineering, Univerzitna 1, 010 26, Žilina, Slovakia e-mail: dana. stancekova@fstroj.uniza.sk

${ }^{3}$ Lublin University of Technology, Faculty of Mechanical Engineering, Nadbystrzycka 36, 20-618 Lublin, Poland, e-mail: i.miturska@pollub.pl

Received: 2018.05.09

Accepted: 2018.06.06

Published: 2018.09.01

\begin{abstract}
Treatment of metal alloys is one of the ways to affect the properties of the material. The article describes an experiment realized at FPTM UJEP when was experimentally studied the influence of alloys AlSi9CuMnNi calcium modification on some of its properties. The alloy was modified with various amounts of calcium and subsequently machining. Also hardness was measured in the resulting alloys. Machining was performed under certain cutting conditions. After machining the obtained chip was evaluated. Chip was evaluated for its shape, length and amount of chips per $100 \mathrm{~g}$. Devices in FPTM laboratories were used to prepare experimental casts and to evaluate hardness and chips, like the melting furnace LAC K70/13, hardness tester Ernst AT 250X or microscope Olympus SZX 10. Experimental quantities of calcium was $0.05,0.1$ and $0.15 \mathrm{wt}$ \%. Presented experiments are part of the extensive research undertaken at Faculty of Production Technologies and Management at Jan Evangelista Purkyně University in Ústí nad Labem.
\end{abstract}

Keywords: alloy, modification, calcium, machining, chip.

\section{INTRODUCTION}

For various reasons, the alloy are adjusting (alloyed, inoculated and modified), which of course also applies to aluminum alloys. These reasons are eg. to improve the physical and technological properties. At the FPTM in this context implement various experiments just with aluminum alloys. One of them is research the effect of different amounts of selected elements to certain aluminum alloys $[9,10]$.

One of the investigated element is calcium, which can be used as the modifying element, in particular of Al-Si alloys. This improves the morphology of silicon in the alloy. It also improves the castability of aluminum alloys. But also it has negative effects, e.g. deterioration of the homogeneity of the resulting structure and is therefore considered as the harmful element. As research shows, the important thing is the amount of this $[3,9,10,17]$.

One of the issues addressed is the research of the influence of various modifiers on the final properties of the alloys, even in terms of machining. Therefore, in this area at FVTM UJEP there are realized the experiments, too. One of which this article describes, when experimental alloy is AlSi9CuMnNi, which belongs to the heat-curable alloys to which the mechanical properties after heat treatment can vary widely depending to copper content. With this specific alloy has been besides studied the influence of calcium amount to the process of forming the chip during the machining, because the assumption was that 
Table 1. Marking of experimental samples

\begin{tabular}{|c|c|c|c|c|c|c|c|c|c|c|c|c|}
\hline Sample No. & $\mathbf{1}$ & $\mathbf{2}$ & $\mathbf{3}$ & $\mathbf{4}$ & $\mathbf{5}$ & $\mathbf{6}$ & $\mathbf{7}$ & $\mathbf{8}$ & $\mathbf{9}$ & $\mathbf{1 0}$ & $\mathbf{1 1}$ & $\mathbf{1 2}$ \\
\hline Wt.\% Ca & \multicolumn{8}{|c|}{0.1} \\
\hline
\end{tabular}

Table 2. The chemical composition of the alloy AlSi9CuMnNi

\begin{tabular}{|c|c|c|c|c|c|}
\hline Element & Al & Si & $\mathbf{C u}$ & $\mathbf{M n}$ & $\mathbf{N i}$ \\
\hline Wt. $\%$ & 87 & 10 & 1.2 & 0.6 & 1.2 \\
\hline
\end{tabular}

modifcated structure will have better influence on machining $[2,11]$.

The use of calcium as a modifier is currently under discussion because the presence of calcium in the aluminum alloy can also have a negative impact. In a small amount, calcium may positively influence the resulting alloy structure and, consequently, its resulting properties (e.g., due to machining). In larger quantities, calcium has an influence on the undesired gasification of the alloy, which results in an increase in the porosity of the resultant structure $[9,10,16]$.

The paper reports on part of the research carried out on FVTM precisely in the area of influence of different amounts of calcium on different aluminum alloys, especially from the siluminous group.

\section{EXPERIMENT}

Three casting groups were made, which alloyed by varied amounts of calcium $(0.05,0.1$ and 0.15 wt. \%). In each group, they were created four casts (Tab. 1).

The actual alloy was produced in the laboratory at FPTM of pure aluminum, the alloying elements (silicon, copper and manganese) have been used in the form of pure metal. Nickel was added as a powder master alloy AlNi75. Calcium was then added as a master alloy AlCa10. The actual melting took place in a furnace LAC K70/13 (Fig. 1) at $760{ }^{\circ} \mathrm{C}$.

The Fig. 2 shows one of the resulting castings. The Tab. 2 summarizes the chemical composition of the experimental alloy, which was, as already mentioned above, modified by appropriate amounts of $\mathrm{Ca}[14,16]$.

The resulting castings were subsequently machinedandwascontinuouslycollectedchip, inorder to compare and evaluate the influence of the amount of $\mathrm{Ca}$ to the chip form. Cutting conditions were determined based on the type of machine and tool, wherein the input data for determining cutting conditions were the maximum machine speed and a range of cutting tool parameters.
The tool being used indexable cutting inserts Pramet DCMT 070202E-UR (Tab. 3). These inserts are suitable for machining of non-ferrous metals.

On the basis of the recommended cutting conditions for these cutting inserts and the possibility used machine was chosen maximum allowed values due to the maximum insert load. Based on the above input conditions was therefore chosen feed

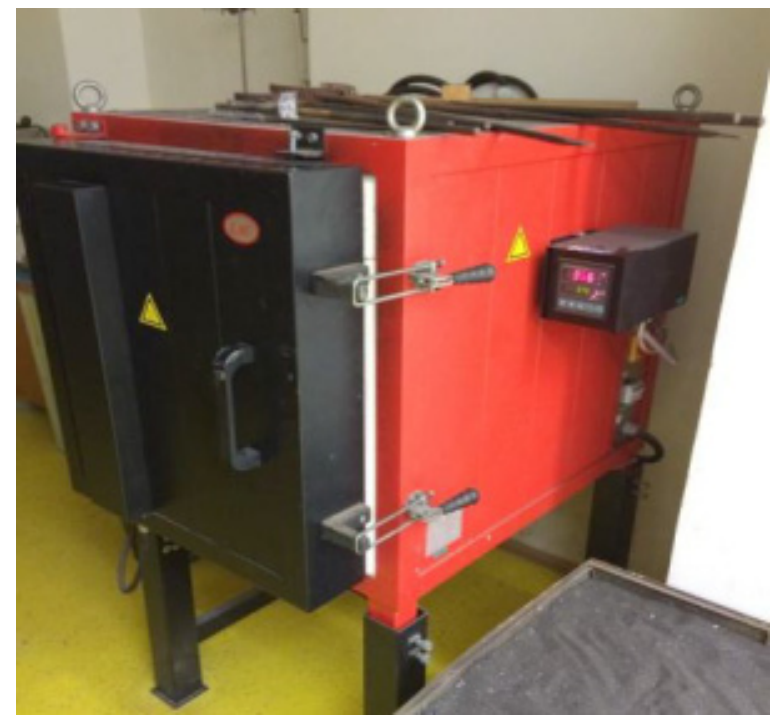

Fig. 1. The melting furnace LAC K70/13

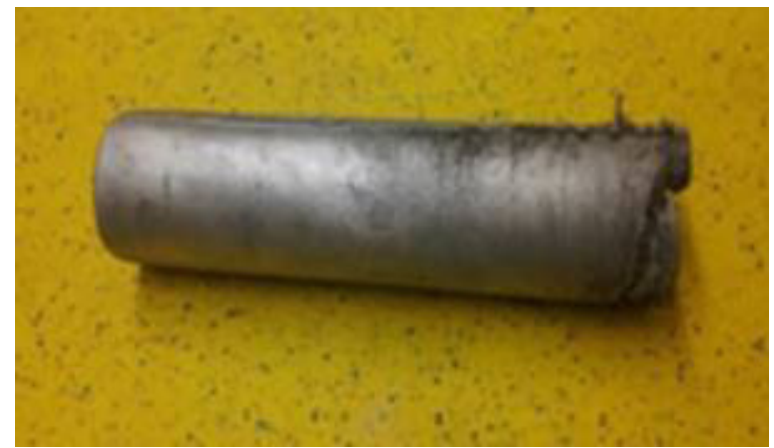

Fig. 2. Sample of casting 
Table 3. Characteristic of cutting plate (insert) DCMT 070202 E-UR

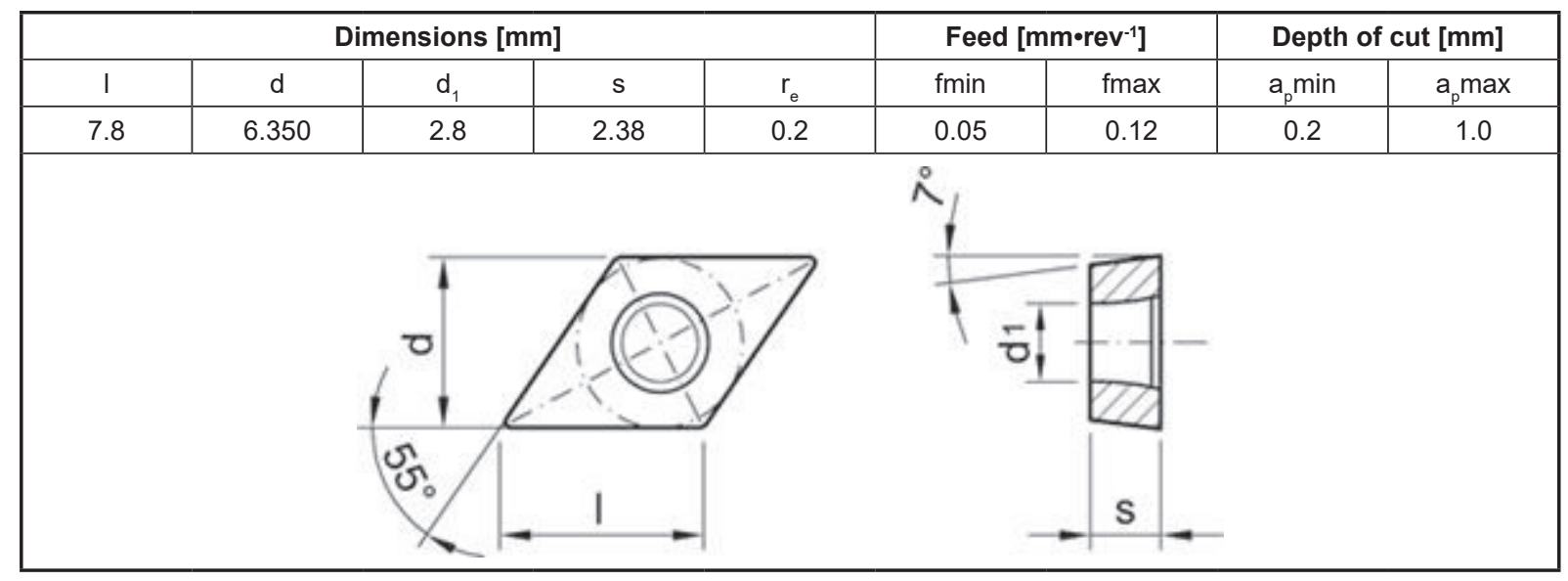

per revolution $\mathrm{f}=0.12 \mathrm{~mm} / \mathrm{rev}$ and depth of cut $\mathrm{a}_{\mathrm{p}}$ $=1 \mathrm{~mm}$. Cutting speed was chosen as the maximal possible realizable $\mathrm{v}_{\mathrm{c}}=200.95 \mathrm{~m} / \mathrm{s}$ with respect to the machine.

For machining was used lathe Emco Mat (Fig. $3)$, which is available at FPTM $[1,4,6,13]$. In

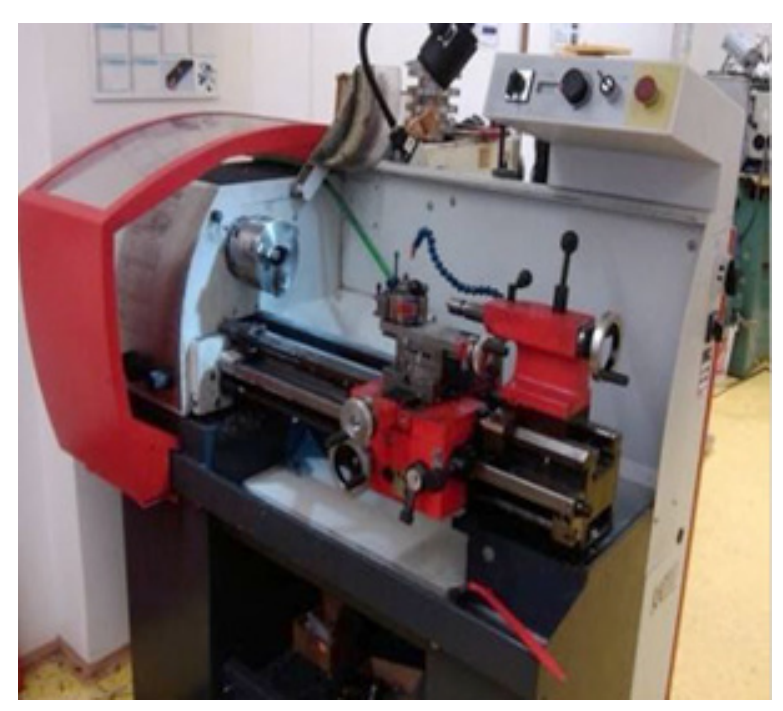

Fig. 3. Lathe Emco Mat

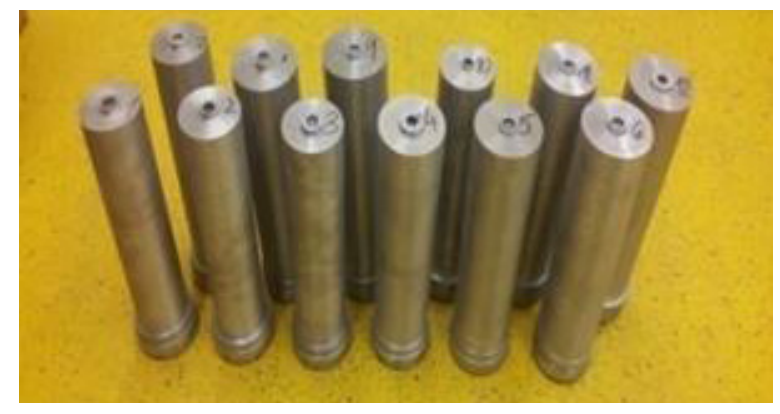

Fig. 4. Samples for machining

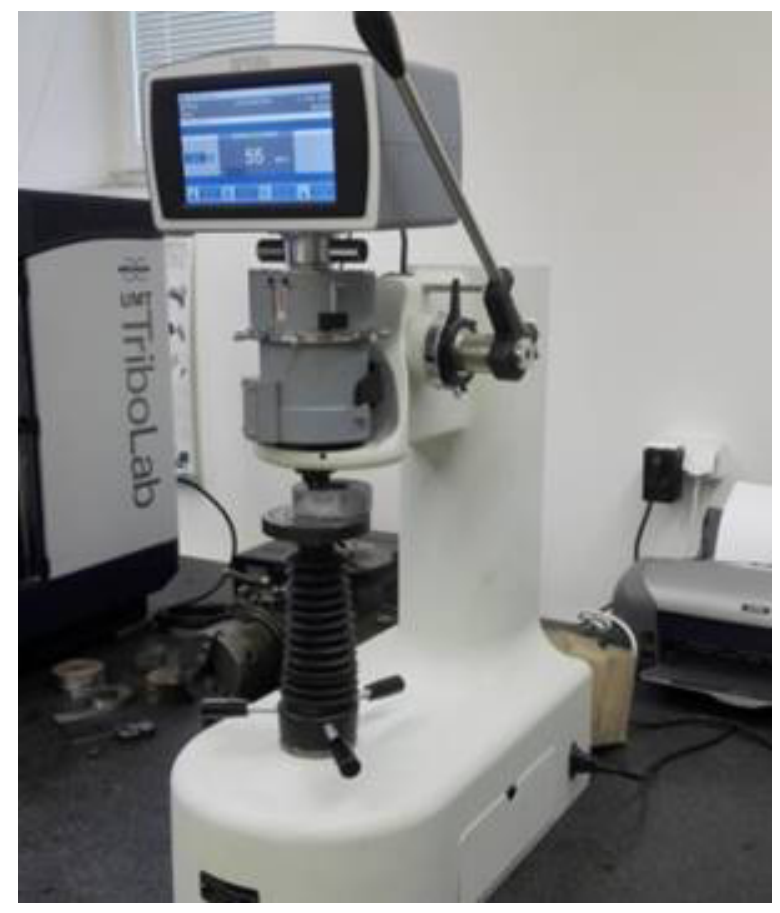

Fig. 5. Hardness tester Ernst AT 250X

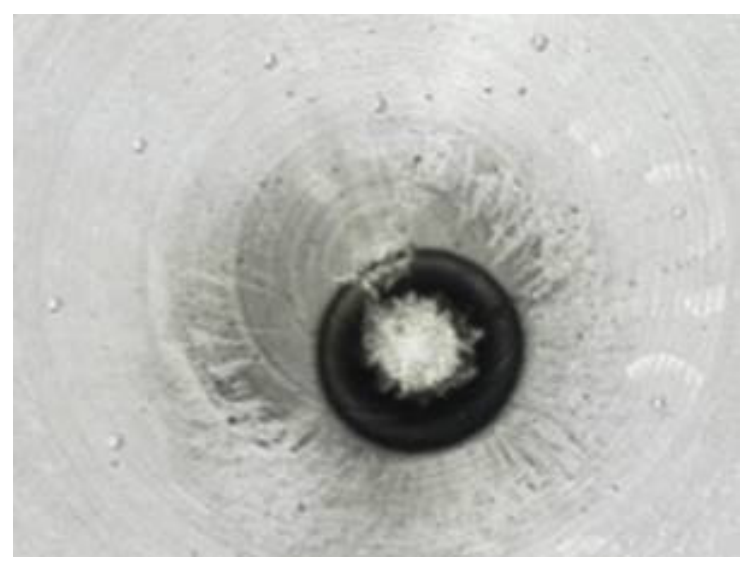

Fig. 6. Sample after hardness measurement 
Table 4. The number of chips per $100 \mathrm{~g}$

\begin{tabular}{|c|c|c|c|c|c|c|c|c|c|c|c|}
\hline \multicolumn{12}{|c|}{ Wt. \% Ca } \\
\hline \multicolumn{4}{|c|}{$0.05 \% \mathrm{Ca}$} & \multicolumn{4}{|c|}{$0.1 \% \mathrm{Ca}$} & \multicolumn{4}{|c|}{$0.15 \% \mathrm{Ca}$} \\
\hline No.S. & No.Ch. & $\bar{n}$ & $\pm \sigma$ & No.S. & No.Ch. & $\bar{n}$ & $\pm \sigma$ & No.S. & No.Ch. & $\bar{n}$ & $\pm \sigma$ \\
\hline 1 & 678.4 & \multirow{4}{*}{626.48} & \multirow{4}{*}{40.9} & 5 & 631.3 & \multirow{4}{*}{625.12} & \multirow{4}{*}{32} & 9 & 628.1 & \multirow{4}{*}{619.01} & \multirow{4}{*}{18.9} \\
\hline 2 & 583.4 & & & 6 & 665.8 & & & 10 & 606.1 & & \\
\hline 3 & 654.5 & & & 7 & 576 & & & 11 & 596.7 & & \\
\hline 4 & 589.6 & & & 8 & 627.4 & & & 12 & 645.2 & & \\
\hline
\end{tabular}

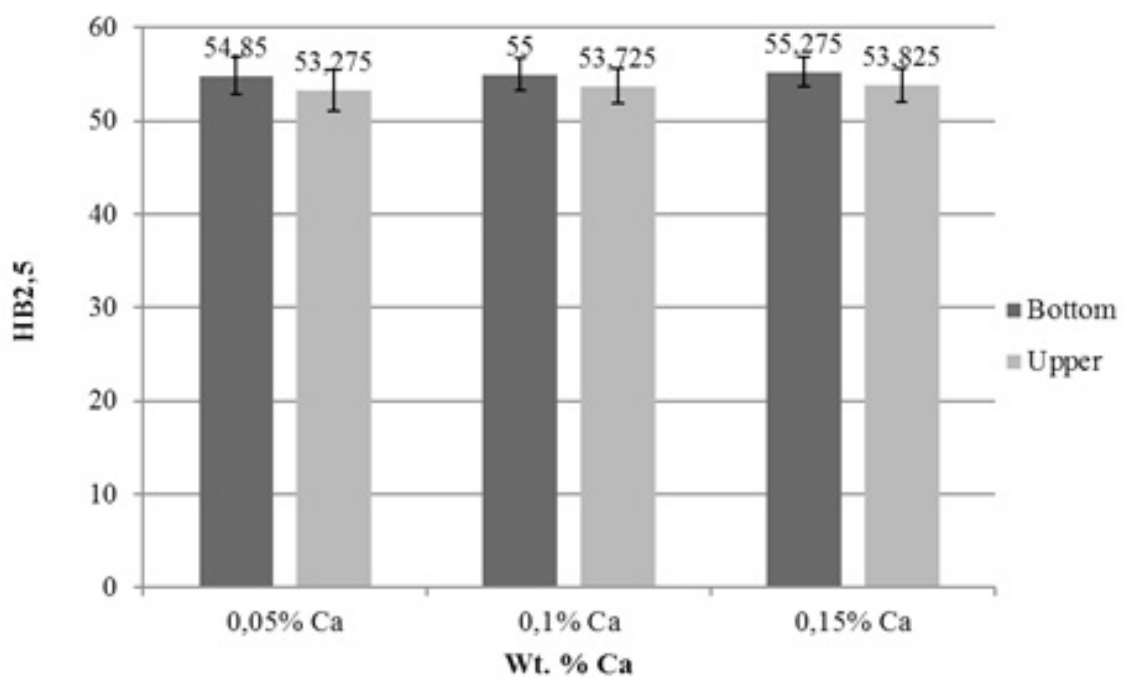

Fig. 7. Comparison of hardness for individual alloys

Fig. 4 there are the samples ready for itself machining for chip analysis.

During the experiment for every machining cast the chips were collected, which were then evaluated.

The Brinell hardness of samples was also measured according to standard EN ISO 65061 on the hardness tester Ernst AT 250X (Fig. 5). The hardness measurement was performed on turned samples by injection a ball with $2.5 \mathrm{~mm}$ diameter at a load of $62.5 \mathrm{kp}(612.916 \mathrm{~N})$ for 10 seconds (Fig. 6).

\section{ANALYSIS AND MEASUREMENT}

Sample hardness measurements were made in twelve measurements at the bottom and top of the cast. The measured values are summarized in the graph in Fig. 7. It can be seen from this graph that at the bottom of the casting the hardness was slightly higher than at the top of the casting. Further, when comparing the hardness for each type of alloy, it appears that the modification of calcium to AlSi9CuMnNi alloy hardness had virtually no effect.
Chip formed by machining the experimental castings was evaluated in terms of the number of chips per $100 \mathrm{~g}$, in terms of shape and in terms of its length $[7,12]$.

The first evaluation of chip was the evaluation in terms of number of chips per $100 \mathrm{~g}$. Of the total quantity of collected chips were always selected fifty chips so as to be in equilibrium ratio, in terms of both length and shape. Fifty of these chips were then weighed on a digital laboratory scale TSCALE.

After determining the weights of individual samples of chips held recalculation of the number of chips per $100 \mathrm{~g}[5,8,15]$. From this measurement showed that the chips when changing the amount of calcium behaved essentially the same, therefore, were observed minimal differences in the number of chips per $100 \mathrm{~g}$ for an individual species of the melt.

Influence of the $\mathrm{Ca}$ amount in the alloy was not thus in this area of analysis confirmed.

In Tab. 4 are summarized measured values.

Fig. 8 shows the graph for a comparison of the chips number for each amount of $\mathrm{Ca}$ in the al- 


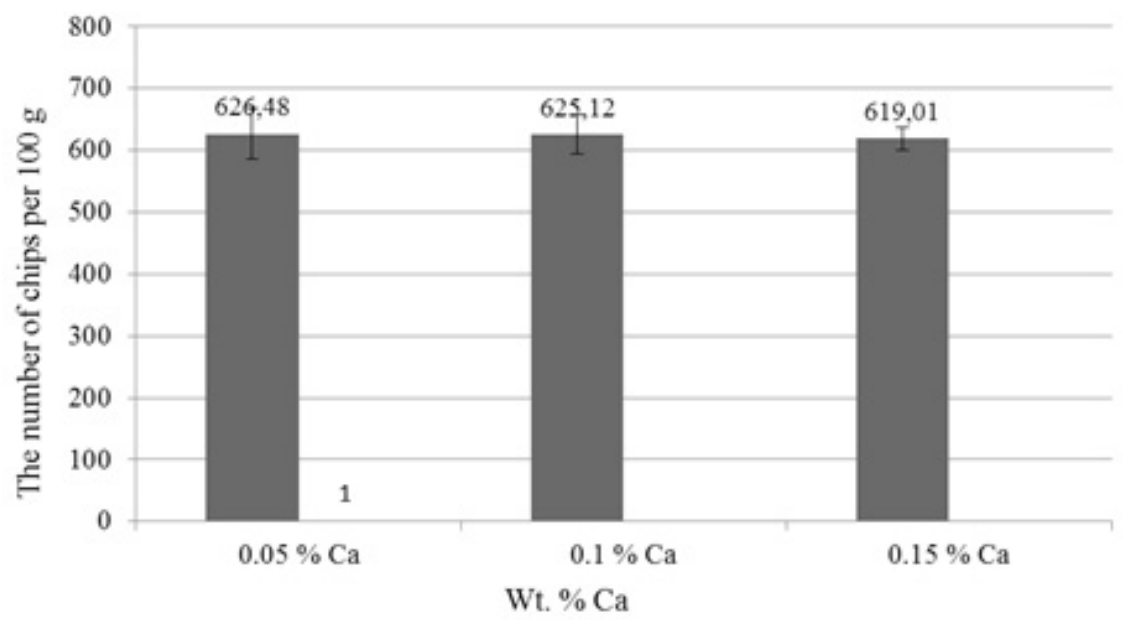

Fig. 8. Comparison of the number of chips per $100 \mathrm{~g}$ for different $\mathrm{Ca}$ amount

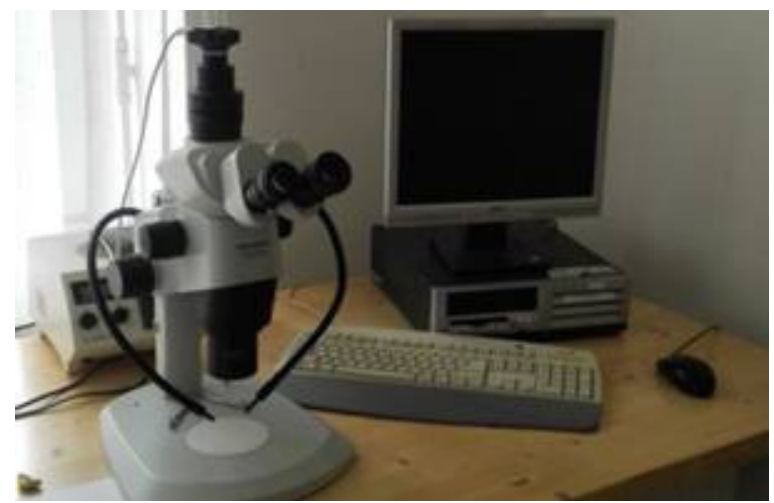

Fig. 9. Microscope Olympus SZX 10

loy. From this is visible, that influence on the chip in this aspect is insignificant.

Another evaluation was evaluation in terms of length and shape of the obtained chips. The size and shape of the chips were evaluated using microscope Olympus SZX 10 (Fig. 9).

The chips collected after machining of experimental castings had rather long shape with a trace in a spiral. Wherein the the effect of calcium on the chip shape was observed primarily a larger quantity of chips more twisted into a spiral when this amount is increased with higher calcium content.

In Fig. 10., 11. and 12. are examples of the chips shape for the different types of castings, ther this fact is visible. From machining point of view, all presented chips are acceptable. In terms of shape, there is not much difference between chips. The influence of calcium amount on chip shape in the presented cases was small.

Furthermore, from each sample the thirty chips were measured by dispose the line method

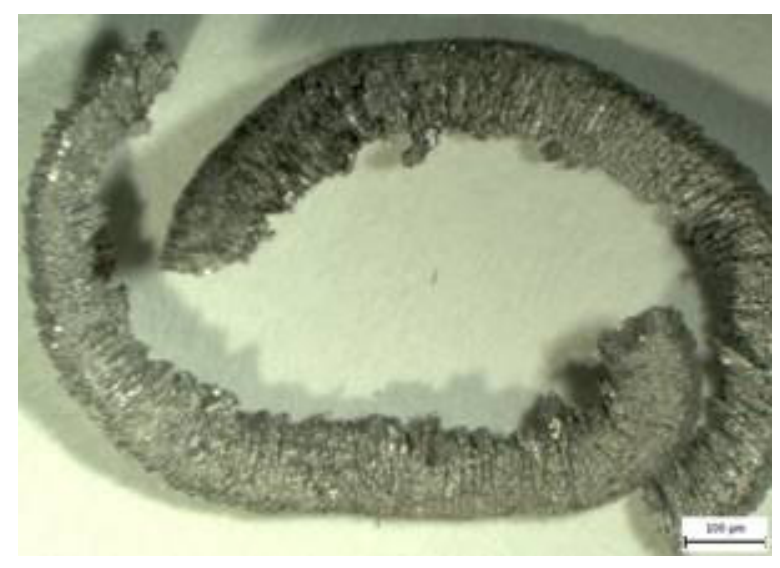

Fig. 10. The chips for the sample $1(0.05 \% \mathrm{Ca})$

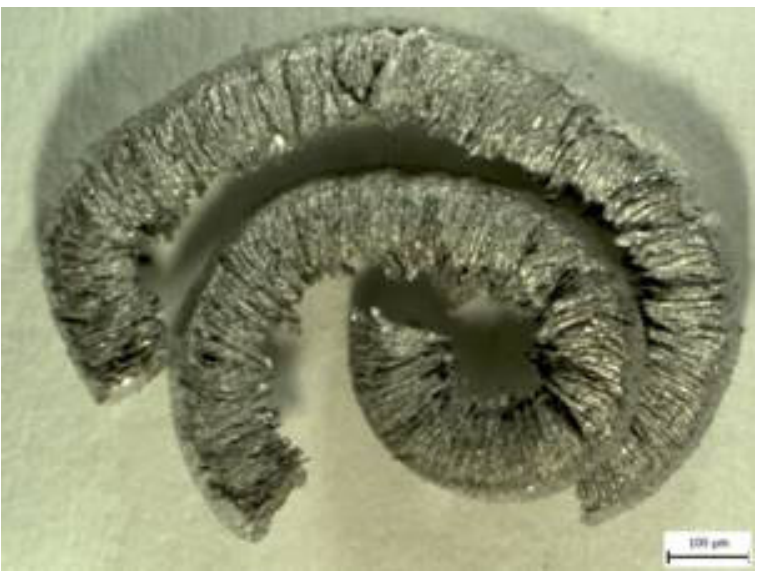

Fig. 11. The chips for the sample $7(0.1 \% \mathrm{Ca})$

to determine the length of the chip (Fig. 13.). For measurement the software QuickPHOTO CAMERA 3.0 was used. In Tab. 5 there are are the summarized measured values. 
Table 5. Lenght of chip

\begin{tabular}{|c|c|c|c|c|c|c|c|c|c|c|c|}
\hline \multicolumn{12}{|c|}{ Wt. \% Ca } \\
\hline \multicolumn{4}{|c|}{$0.05 \% \mathrm{Ca}$} & \multicolumn{4}{|c|}{$0.1 \% \mathrm{Ca}$} & \multicolumn{4}{|c|}{$0.15 \% \mathrm{Ca}$} \\
\hline No.S.. & $\bar{l} v z$ & $\bar{l}$ & $\pm \sigma$ & No.S.. & $\bar{l}_{v z}$ & $\bar{n}$ & $\pm \sigma$ & No.S. & $\bar{l} v z$ & $\bar{l}$ & $\pm \sigma$ \\
\hline 1 & 11328 & \multirow{4}{*}{12814} & \multirow{4}{*}{2149} & 5 & 14076 & \multirow{4}{*}{14096} & \multirow{4}{*}{2096} & 9 & 12462 & \multirow{4}{*}{13428} & \multirow{4}{*}{2090} \\
\hline 2 & 13088 & & & 6 & 13761 & & & 10 & 13441 & & \\
\hline 3 & 12762 & & & 7 & 14306 & & & 11 & 13811 & & \\
\hline 4 & 14077 & & & 8 & 14239 & & & 12 & 13999 & & \\
\hline
\end{tabular}

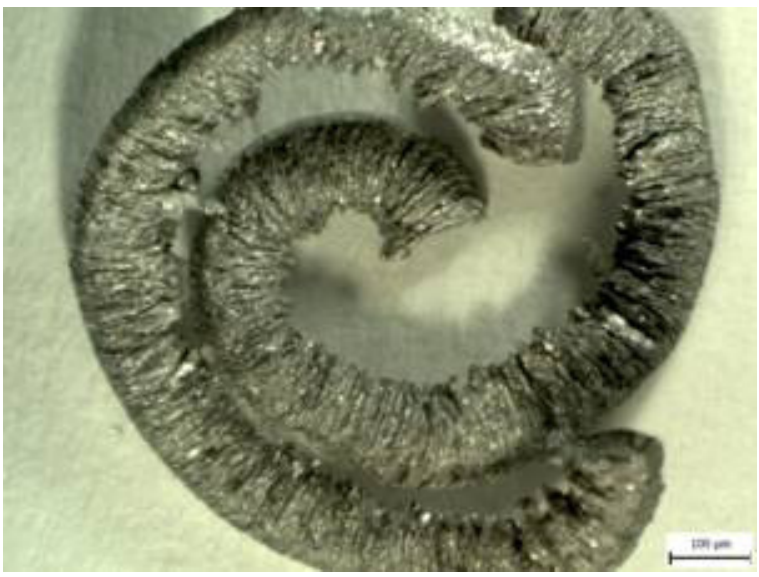

Fig. 12. The chips for the sample $12(0.15 \% \mathrm{Ca})$

The Fig. 14. shows a graph comparing the average chip size for aech Ca quantity in the experimental alloy. It is evident that the differences in the size of chips are minimal. The minimum length of the chip was measured for 0.05 wt. \% $\mathrm{Ca}$, the longest chip was measured for $0.1 \mathrm{wt}$. \% $\mathrm{Ca}$. But these differences are not significant. It is true that the use of calcium as a modifier is recommended quantity max. 0.05 wt. \% Ca.

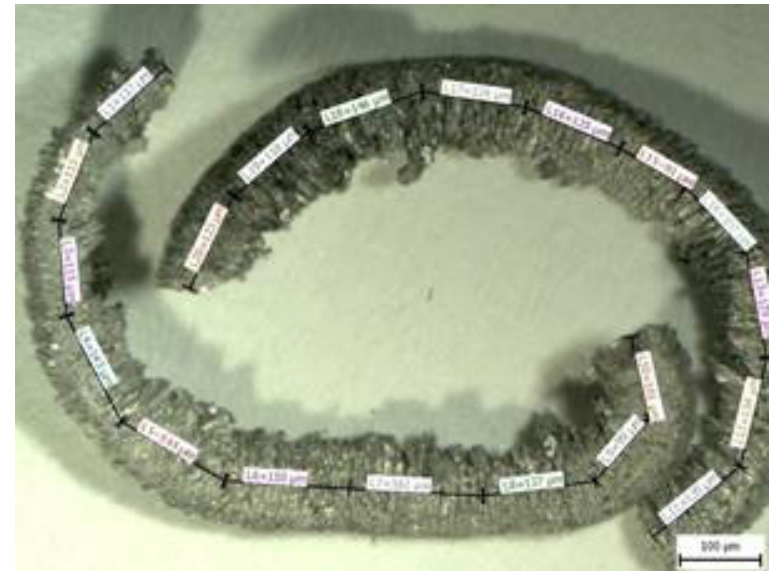

Fig. 13. Sample of measurement chip size

\section{CONCLUSIONS}

In the context of the presented experiment was made twelve samples and for each of the $\mathrm{Ca}$ amount in the alloy were prepared four samples. The alloy was made at FPTM using pure metals and master alloys. Castings were analyzed among others in terms of hardness final alloys and size and shape of the chips, formed after machining the individual castings.

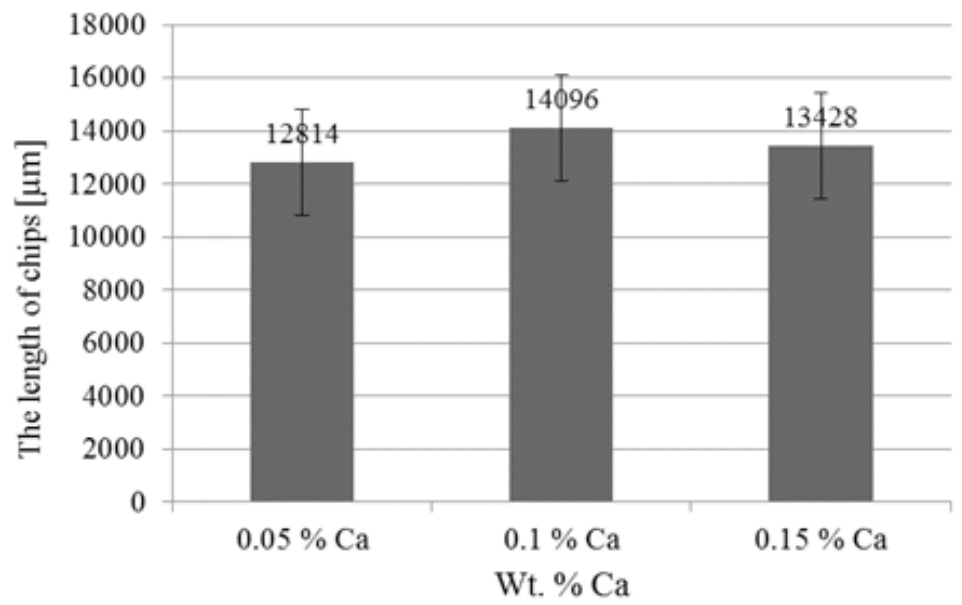

Fig. 14. Comparison of chip sizes for each $\mathrm{Ca}$ amounts 
After the performed measurements it can be stated that the hardness was virtually the same for all $\mathrm{Ca}$ amount in the alloy, so the amount of $\mathrm{Ca}$ had no influence on this property.

The chips collected after machining werein terms of their shape tended to be longer with a trace in a spiral shape, with the effect of calcium at chip shape were observed mainly higher incidence spiral chip with increasing calcium content. In terms of the length of the chips were observed differences between melts very small and it is difficult to deduce from them that the amount of $\mathrm{Ca}$ have an effect.

From the perspective of the machining the chips for all kinds of castings were on the whole acceptable. Even comparing the quantity of chips per $100 \mathrm{~g}$ for the each kinds of melts showed no significant differences in this.

There may be noted that the test amount of $\mathrm{Ca}$ in the experimental alloy AlSi9CuMnNi in the term of the hardness and chip formation when machining had virtually no effect.

The presented results are a part of other relatively large long-term experiments performed at FPTM JEPU in Ústí nad Labem.

\section{Acknowledgement}

Authors are grateful for the support of grant No. CZ.1.05/4.1.00/11.0260 EDIMARE.

\section{REFERENCES}

1. Bumbalek, B. Fyzikální podstata řezání, [online], VUT Brno, Fakulta strojního inženýrství, 2005, [cit 2016-03-09]. Avalaible on www: <http://ust. fme.vutbr.cz/obrabeni/opory/Opora05_Fyzikalni_ podstata_rezani.pdf $>$.

2. Cais, J. Ovlivňování struktury a vlastností $\mathrm{Al}-\mathrm{Si}$ slitin pomocí antimonu. Diplomová práce, FVTM UJEP, 2011.

3. Cervinka, R. Vliv modifikace slitiny AlSi9CuMnNi antimonem na její obrobitelnost. Diplomová práce, FVTM UJEP, 2015.

4. Childs, T., Maekawa, K., Obikawa, T., Yamane, Y. Metal Machining: Theory and applications. Arnold, London, Great Britain, 2000.

5. Formanek, J., Kucerova, L., Tochylin, M. The Hazards of Defects and Poor Quality of Aluminium
Materials. Proc. of $24^{\text {th }}$ Internatioanl Conference on Metallurgy and Materials Metal 2015, Brno, Czech Republic 2015, 1552-1557.

6. Humar, A. Technologie I., Technologie obrábění - 1. část [online], Studijní opory pro magisterskou formu studia VUT Brno, Fakulta strojního inženýrství, 2003, [cit 2016-03-09]. Avalaible on www: $<$ http://ust.fme.vutbr.cz/obrabeni/oporysave/TI_TO-1 cast.pdf>.

7. Kusmierczak, S. Usage of Technical Equipment in Teaching Technical Subjects. Proc. of $14^{\text {th }}$ International Scientific Conference Engineering for Rural Development, Jelgava, Latvia 2015, 748-752.

8. Maruda, R.W., Krolczyk, G., Nieslony, P. et al. The influence of the cooling conditions on the cutting tool wear and the chip formation mechanism. Journal of Manufacturing processes, 24, 2016, 107-115.

9. Michna, S., Kusmierczak, S. Technologie a zpracování hliníkových materiálů. Šolc tisk, Děčín, 2008.

10. Michna, S., Lukac, I., Ocenasek, V., Koreny, R., Drapala, J., Schneider, H., Miskufova, A. a kol. Encyklopedie hliníku. Adin, Prešov, 2005.

11. Naprstkova, N., Cais, J., Sviantek, J., Cierna, H. Change of selected resulting properties of AlSi$9 \mathrm{CuMnNi}$ alloy by heat treatment and antimony. Proc. of $15^{\text {th }}$ International Scientific Conference Engineering for Rural Development, Jelgava, Latvia 2016, 1133-1138.

12. Naprstkova, N., Kalincova, D. Influence of Additional Chemical Components on Machining Properties of Selected Aluminium - Silicon Alloy. Proc. of $14^{\text {th }}$ Internationa Scientific Conference Engineering for Rural Development, Jelgava, Latvia 2015, 766-771.

13. Naprstkova, N., Kusmierczak, S. Analysis of Decrease Machinability Possible Causes for Claimed Alloy, Advances in Science and Technology - Researche Journal, 10 (31), 2016, 94-101.

14. Náprstková, N., Kusmierczak, S., Cais, J. Modification of AlSi7Mg0.3 alloy by strontium. Manufacturing Technology, 13 (3), 2013, 373-380.

15. Rudawska, A. Influence of the Thickness of Joined Elements on Lap Lenght of Aluminium Alloy Sheet Bonded Joints. Advaces in Science and Technology - Researche Journal, 9 (27), 2015, 35-44.

16. Strihavkova, E. Výzkum vlastností nových slitin typů $\mathrm{Al}-\mathrm{Si}$ legovaných vápníkem. Disertační práce, FVTM UJEP, 2014.

17. Vojtech, D. Kovové materiály. VŠCHT, Praha, 2006. 